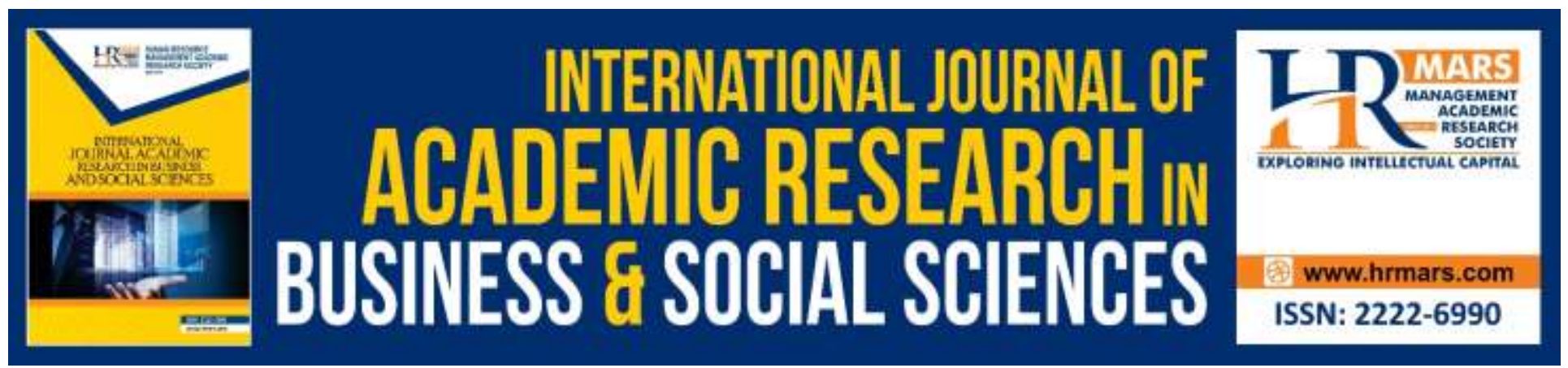

\title{
An Appraisal of ASEAN Defence Ministers Meeting (ADMM) as Part of Defence Diplomacy Initiative for Conflict Resolution
}

Mazura Md Saman, Salma Yusof, Jamal Rodzi Dahari, Azlan Iskandar Abdul Ghani

To Link this Article: http://dx.doi.org/10.6007/IJARBSS/v9-i6/6059

DOI: $10.6007 /$ IJARBSS/v9-i6/6059

Received: 15 April 2019, Revised: 01 May 2019, Accepted: 01 June 2019

Published Online: 23 June 2019

In-Text Citation: (Saman, Yusof, Dahari, \& Ghani, 2019)

To Cite this Article: Saman, M. M., Yusof, S., Dahari, J. R., \& Ghani, A. I. A. (2019). An Appraisal of ASEAN Defence Ministers Meeting (ADMM) as Part of Defence Diplomacy Initiative for Conflict Resolution. International Journal of Academic Research Business and Social Sciences, 9(6),976-987.

\section{Copyright: (c) 2019 The Author(s)}

Published by Human Resource Management Academic Research Society (www.hrmars.com)

This article is published under the Creative Commons Attribution (CC BY 4.0) license. Anyone may reproduce, distribute, translate and create derivative works of this article (for both commercial and non-commercial purposes), subject to full attribution to the original publication and authors. The full terms of this license may be seen

at: http://creativecommons.org/licences/by/4.0/legalcode

Vol. 9, No. 2, 2019, Pg. 976 - 987

http://hrmars.com/index.php/pages/detail/IJARBSS

JOURNAL HOMEPAGE

Full Terms \& Conditions of access and use can be found at http://hrmars.com/index.php/pages/detail/publication-ethics 


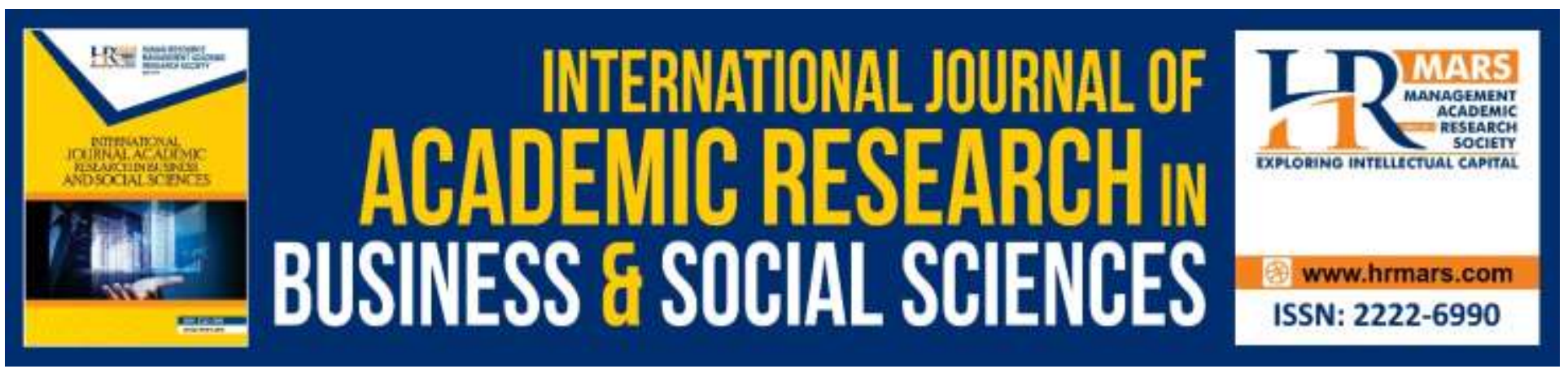

\title{
An Appraisal of ASEAN Defence Ministers Meeting (ADMM) as Part of Defence Diplomacy Initiative for Conflict Resolution
}

\author{
Mazura Md Saman, Salma Yusof, Jamal Rodzi Dahari, Azlan \\ Iskandar Abdul Ghani
}

Faculty of Defence Studies and Management, National Defence University of Malaysia, Sungai Besi

Camp, 57000 Kuala Lumpur, Malaysia

\begin{abstract}
Defence diplomacy is an effective tool to promote understanding among militaries and armed forces of sovereign nations. It usually involves the use of military personnel or forces in pursuing foreign policy initiatives. More often it is incorporated in the respective state's security strategy and policies thereunder. This paper assesses the significance of ASEAN Defence Ministers Meeting as one of the defence diplomacies instruments in ASEAN and its capabilities in resolving conflicts within the region. In doing so, this paper will look into the progress of ADMM since its institution in 2006, whilst not neglecting the influence of ASEAN norms, and analyse the capabilities of ADMM in tackling regional security issues. It is argued that ADMM roles rather limited, the norm of non-interference being considered a barrier, and it lacks ministerial mandate. Thus, ADMM remains as a dialogue tool rather than an effective conflict resolution platform.
\end{abstract}

\section{Introduction}

'Defence diplomacy' was once labelled as the sweet agony in the area of international and foreign relation, as well as in the domain of security policy. However, it is now, becoming an imperative instrument in conflict resolution within the ambit of a nation's security policy and foreign relation. In Southeast Asia region, defence diplomacy, through 'The Association of Southeast Asian Nations' (ASEAN), the most significant entity of regionalist pact in the region, plays major roles in ensuring regional stability and security. The main objective of the formation of ASEAN is mainly for member nations economic growth, social and cultural progress, culture, protection of the peace and stability. It also serves as an open platform for peaceful negotiations among the members. Indonesia, Malaysia, Singapore, Thailand and Philippines were the first five member nations. Brunei Darussalam became the sixth member, joining the pact on 7 January 1984, followed by Vietnam on 28 July 1995, Lao People's Democratic Republic and Myanmar on 23 July 1997, and Cambodia on 30 April 1999, 
with a total of ten member nations of ASEAN as of today. Since its formation, the organisation has endeavoured various methods and instruments intended for peaceful ways of conflicts resolution and at the same time maintaining the norm of ASEAN that is the code of non-interference in the internal conflicts of member states as well as non-confrontational approaches to conflicts. Among the mechanism utilised by ASEAN in managing stability in the region is, inter alia, through the ASEAN Defence Ministerial Meeting (ADMM). This article is intended to examine the ASEAN Defence Ministerial Meeting (ADMM) as a peace initiative mechanism in defence diplomacy utilised by ASEAN as a method of conflict resolution.

\section{Defining Defence Diplomacy}

Discussion on definition of 'defence diplomacy' evolves around its concept rather than deliberation on the linguistic approach. Ironically, the two words; 'defence' and 'diplomacy', represent two contrasting values. Diplomacy implicates 'pacific-persuasive (diplomatic) approach to implement related foreign policy directives' (Edmonds \& Mills, 1998, p. 106). It is traditionally seen as political, peaceful and straightforward method of foreign policy involving the sending of ambassadors or authorised representatives in foreign nations. On the other hand, defence usually implicates violentcoercive and conventionally associated with the situation of using the 'armed force (offensive, defensive or deterrent) either in armed conflict, the circumstances short of war such as military threats, military intervention, military aid and assistance and the pacific use of military in peace support operations' (Anton du Plesis, 2008).

While there is no collective meaning of defence diplomacy, the combination of the two words is comprehensible and self-explanatory. It is putative understanding that it involves peacetime collaborative activities between nations' armed forces and military entities (Bitzinger, 2016). In limited scope, defence diplomacy is characterised as the 'use of military personnel, including service attaches, in support of conflict prevention and resolution. Among a great variety of activities, it includes providing assistance in the development of democratically accountable armed forces' (Berridge et al., 2003, p. 66). A wider context defined by Cottey and Forster (2004) describes defence diplomacy as 'the peacetime cooperative use of armed forces and related infrastructure (primarily defence ministries) as a tool of foreign and security policy'. It involves a wide range of engagements and arrangements such as 'bilateral and multilateral contacts between senior military and civilian defence officials, appointment of defence attachés to foreign countries, bilateral defence cooperation agreements, training of foreign military and civilian defence personnel, provision of expertise and advice on the democratic control of armed forces, defence management and military technical areas, contacts and exchanges between military personnel and units and ship visits, placement of military or civilian personnel in partner countries' defence ministries or armed forces, deployment of training teams, provision of military equipment and other material aid and bilateral or multilateral military exercises for training purposes' (Cottey and Foster, 2004). Thus, defence diplomacy would be fostered through foreign relation activities, military education, military exercises and humanitarian assistance, bilaterally or multilaterally. The main aim of 'defence diplomacy' is to serve 'specific foreign and security objectives by engaging cooperative relationship with potential enemies especially neighbouring nations. It also facilitates conflict prevention by building trust, 
INTERNATIONAL JOURNAL OF ACADEMIC RESEARCH IN BUSINESS AND SOCIAL SCIENCES

Vol. 9, No. 6, June, 2019, E-ISSN: 2222-6990 @ 2019 HRMARS

introduce transparency, reinforce perception of common interest among those nations' (Anton Du Plesis, 2008).

\section{Defence and Security Cooperation in ASEAN}

Since 1950s, countries in the Southeast Asian region have involved in defence and security collaboration bilaterally or multilaterally. To illustrate some of those defence and security cooperation are Southeast Asia Treaty Organisation (SEATO), the Anglo-Malayan/ Malaysian Defence Agreement (AMDA) and Five Power Defence Arrangements (FDPA).

In September 1954, Thailand and the Philippines joined SEATO (also known as Manila Pact). The membership comprising the United States, Australia, New Zealand, Great Britain, France and the Islamic Republic of Pakistan. While the name of the organisation related to Southeast Asia, only two countries from the region joined the pact. The other nations involvements were to maintain their interest in the region. It was a military alliance created to curb the communist aggression and subversion. However, SEATO's plans for military intervention fell short due to the concerns over retaliation from Communist countries, namely Communist China and the USSR. The organisation's failure led many people to dub SEATO as just a paper tiger. As a result of futile efforts, the organisation was disbanded in 1977 (Farrell, 2011).

The AMDA took effect on 12 October 1957, after Malaya's independence. Its objective was to enable the British, to legally stationed British troops in its former colony, Malaya. It was the expression of British commitment in the security of its' former colony. However, in 1967, British announced its intention to end its defence commitment "East of Suez" and this include AMDA. AMDA's commitment was contingent to the British financial implication, and that time, British suffered economic crisis. AMDA was subsequently superseded by the more flexible Five Power Defence Agreement (FDPA), involved Australia, New Zealand, Great Britain, Malaya and Singapore, without tight fiduciary commitment of British Government. Australia and New Zealand joined AMDA in 1956 and Singapore in 1961 ( Ooi, Gin, 2004, p. 163).

FDPA was established in 1971 and it exists until now. The arrangement focuses on the three main activities namely, the "Integrated Area Defence System (IADS), the architecture for political-military dialogue, and the exercise programme" (Bristow, 2005, pp. 1-20). However, these collaborations; SEATO, AMDA and FDPA, were not in the form of regional basis but more on the engagement of western allies with some of the Southeast Asian nation and relationship of colonial powers with former colony in Southeast Asia.

ASEAN came into picture in 1967, with the objective of reducing tensions between Southeast Asia's non-communist states, in so doing, releasing their week post-colonial government to tackle internal communist challenges and to address development priorities. It was an attempt to institutionalise the rapprochement between Malaysia and Indonesia, and to create a framework to build certainty and trust into relations within Southeast Asia (Henderson, 1998, p. 15). ASEAN's founding document, the Bangkok Declaration, claimed for the countries of Southeast Asia "a primary responsibility for strengthening the economic and social stability of the region and ensuring their peaceful and progressive national development", and identified that "they are determined to ensure 
their stability and security from external interference". However, this intention was not replicated in ASEAN's aims and purposes, which simply called for cooperation in "economic, social, cultural, technical, scientific and administrative fields." While anti-communism unified ASEAN's members, its founders defined the organisation in more conventional regional terms. The Bangkok Declaration staled that ASEAN was open to all Southeast Asian states subscribing to the Association's principles and goals - essentially appeals for good neighbourliness. Since its establishment, ASEAN has created numbers of defence and security concept such as "the Zone of Peace, Freedom and Neutrality (ZOPFAN); the Treaty of Amity and Cooperation (TAC) and ASEAN Regional Forum.

ZOPFAN was meant to assure the stability in the region signed by the Foreign Minister of the Founding Members of ASEAN in 1971. The main objective of the TAC is to "enshrined the fundamental principle of mutual respect for each other's sovereignty, freedom from external interference, noninterference in the internal affairs of other member, pacific settlement of disputes, renunciation of threat or use of force and effective cooperation in the relations between and among its members" and ASEAN Regional Forum was established with the objective of fostering "constructive dialogue and consultation on political and security issues of common interest and concern and making significant contributions to efforts towards confidence-building and preventive diplomacy in Asia Pacific Region".

ASEAN currently composed of all ten Southeast Asian countries, is moving towards being a more rules-based organisation in order to better meet the challenges posed by regional integration, the expansion of its external linkages and rapid globalisation, with the eventual aim to remain an effective player on the international arena. In pursuing that goal, the leaders of ASEAN signed a historic charter on November 20th, 2007. This document known as the ASEAN Charter sets the framework and lays the legal foundation for ASEAN to restructure its existing mechanisms and improve its decisionmaking process to enhance efficiency and ensure prompt implementation of all ASEAN agreements and decisions. The Charter also provides ASEAN with a legal personality that enables ASEAN substantially progressed within the agreed terms.

\section{The Institution of ASEAN Defence Ministerial Meeting (ADMM)}

The proposition pertaining to defence cooperation had persistently appeared and reappeared since the institution of ASEAN. However, the idea did not collectively been agreed by many of the ASEANs' participating nations as they were not prepared for broader and deeper arrangements in defence related issues. While waiting the consensus of agreement to the proposition, ASEAN managed to work together within the boundaries based on the agreed fundamental principles of cooperation and good neighbourliness among ASEAN nations as enshrined in the 1967 Treaty of Amity and Cooperation. These principles have then developed the 'norm in the relations among the nations in Southeast Asia as well as in ASEAN's relations with its friends and Dialogue Partners'.

ASEAN member states, in addressing the ever changing security challenges must share the responsibility for strengthening peace, stability and security of the region free from foreign military interference in any form or shape, and this would be best accomplished by a security community in the region, which would be formed through a consistent effort of confidence-building measures and mutual consultations and general consensus in all matters affecting the region. This, however, does 
not mean that security concerns are absent or neglected. In fact, there is extensive security' cooperation among ASEAN members on a bilateral and multilateral basis in an effort to avert any common threat to the members. Bilateral military exercises involving ASEAN states have been carried out since 1977. But it needs to be pointed out that bilateral defence links within ASEAN are not uniformly developed. The majority of bilateral military exercises take place between three countries: Indonesia, Malaysia and Singapore. A good part of recent expansion of defence links in ASEAN has also involved these three states. For instance, the deployment in 2005 of a joint military' force composed of warships, aircraft and surveillance aircraft in the Straits of Malacca. Philippines and Malaysia that have had joint Army exercises from an early date have since 1995 expanded to include Navy and Air Force, and Indonesia and Singapore jointly built in 1994 the Air Combat Manoeuvring Range (ACMR) and expressed their intention to provide it for the use of other ASEAN members. In addition to these conventional joint exercises, there are moves toward joint operation in response to transnational dangers, like the joint maritime patrol by Thailand and Vietnam to prevent fishing boat collisions and smuggling and other illegal activities in the Gulf of Thailand. As a case of comprehensive defence cooperation, the Philippines and Malaysia concluded the Defence Cooperation Treaty on 26 March 1994, as the first such event among the ASEAN members. It is part of ASEAN's culture not to openly speak about security or military cooperation, as it has always been a sensitive issue.

As time passed by, ASEAN has gained maturity and becoming more structured. ASEAN then developed a vision for a community of caring societies, with diverse objectives including economic, political, functional, security, and external relations cooperation. Through its consensus-building approach, ASEAN has shaped a community of nations which are committed to achieve peace, progress, and prosperity in the region in the spirit of equality and partnership. The ASEAN Vision 2020, which was later accelerated to 2015, calls for an organisation that shall 'have established a peaceful and stable Southeast Asia where each nation is at peace with itself and where the causes for conflict have been eliminated, through abiding respect for justice and the rule of law and through the strengthening of national and national resilience'. This would be established by what is now commonly known as ASEAN Political Security Community.

The ASEAN Political Security Community (ASC) began in 2003 as a consequence of several issues within the region such as ASEAN financial crisis in the late 1990's and repercussion of the September 11th World Centre attack. It is meant to promote political and security cooperation within ASEAN, rather that defence pact, military alliances or common foreign policy, all of which were rejected by ASEAN declarations which recognise the sovereign right of member states to pursue individual foreign policies and defence arrangements. The idea was that ASEAN should be perceived to be more proactive in meeting with security issues, to reinvigorate itself so that ASEAN remain relevant within the region and to expand the previously minimal defence cooperation under ASEAN. As part of the efforts to put rhetoric to pragmatism under the ASEAN Security Pillar, ASEAN leaders saw a need to develop more structured framework for defence cooperation under the guidance of ASEAN Defence Ministers in making the institution more resilient and cohesive to address new emerging nontraditional security challenges such as non-state actors' terrorism and piracy. Thus, concerted efforts by forming an effective framework of cooperation is essential, led to the creation of the ASEAN Defence Ministers Meeting (ADMM) framework in 2006. 
ADMM has befitted to become one of the strategies in implementing ASEAN Security Community. ADMM is set to be a platform to facilitate the interactions between the defence and military officials of ASEAN member countries and develop practical cooperation among them in the field of defence and security with the purpose of, among others, firming confidence-building measures through increased opportunities for exchanges and connections. The inauguration of ADMM was historic and significant in ASEAN as it marked the beginning of a formal ASEAN defence track. This was especially crucial in view of the fluid regional security situation and the range of transnational security issues that the region faced. The inaugural meeting of the ASEAN Defence Ministers, held on 09 May 2006 in Kuala Lumpur, responded to a long felt need and marked the formal inclusion of defence and military interactions within the framework of ASEAN. The Concept Paper adopted at the inaugural ADMM views the establishment of the ADMM as complementing other regional efforts that promote security dialogue and cooperation. The ADMM, as the highest ministerial defence and security consultative and cooperative mechanism within ASEAN, puts under its purview existing and future defence and military meetings among ASEAN Member Countries and between ASEAN, its friends and Dialogue Partners. Table 1 shows the timeline in instituting the ADMM.

\section{TABLE 1}

The Institution of ADMM Timeline

\begin{tabular}{|c|c|}
\hline $\begin{array}{l}\text { Declaration of ASEAN } \\
\text { Concord } \\
\text { Indonesia, } 24 \text { February } \\
1976 \text { known as The ASEAN } \\
\text { Concord I } \\
\text { (Bali Concord I) }\end{array}$ & $\begin{array}{l}\text { Envisaged cooperation among the member states in security } \\
\text { matters in accordance with their mutual needs and interests. }\end{array}$ \\
\hline $\begin{array}{l}\text { Declaration of ASEAN } \\
\text { Concord II Indonesia, } 7 \\
\text { October } 2003 \text { known as The } \\
\text { ASEAN Concord II (Bali } \\
\text { Concord II) }\end{array}$ & $\begin{array}{l}\text { Envisioned the establishment of an ASEAN Community with ASEAN } \\
\text { Security Community, ASEAN Economic Community and ASEAN } \\
\text { Socio-Cultural Community as its three pillars. } \\
\text { ASEAN adopted the Declaration of ASEAN seeking to establish a } \\
\text { dynamic, cohesive, resilient and integrated ASEAN Community } \\
\text { by } 2020 \text {, which was later accelerated to } 2015 \text { by the ASEAN } \\
\text { Leaders at the 12th ASEAN Summit in Cebu on January } 13,2007 \text {. } \\
\text { Indonesia (as the ASEAN Chairman) suggested that the ADMM be } \\
\text { included as part of the ASEAN Security Community (ASC) and its } \\
\text { associated Plan of Action in } 2003 \text { and } 2004 \text { respectively }\end{array}$ \\
\hline $\begin{array}{l}\text { 10th ASEAN Summit } \\
29^{\text {th }} \text { November } 2004\end{array}$ & $\begin{array}{l}\text { Signed the Vientiane Action Programme (VAP), a six-year plan for } \\
\text { ASEAN } \\
\text { Outlined, among others, the priority programs to realize the vision } \\
\text { of an ASEAN Security Community }\end{array}$ \\
\hline
\end{tabular}


INTERNATIONAL JOURNAL OF ACADEMIC RESEARCH IN BUSINESS AND SOCIAL SCIENCES Vol. 9, No. 6, June, 2019, E-ISSN: 2222-6990 @ 2019 HRMARS

\begin{tabular}{|l|l|}
\hline & $\begin{array}{l}\text { One of the action programs of the VAP is the establishment of an } \\
\text { annual ASEAN Defence Ministers' Meeting (ADMM). }\end{array}$ \\
\hline $\begin{array}{l}\text { 38th ASEAN Ministerial } \\
\text { Meeting in Vientiane, Laos, } \\
26 \text { July } 2005\end{array}$ & Agreed that the time was right for an ADMM to be convened \\
\hline $\begin{array}{l}\text { Kuala Lumpur in } 9^{\text {th }} \text { May } \\
2006\end{array}$ & Inaugural of ADMM \\
\hline $\begin{array}{l}\text { Singapore, } 14^{\text {th }} \text { November } \\
2007\end{array}$ & Adoption of the concept paper to establish the ADMM-Plus \\
\hline $\begin{array}{l}\text { Hanoi, Vietnam, } 12 \text { October } \\
2010\end{array}$ & The Inaugural of ADMM-Plus \\
\hline
\end{tabular}

At the outset, the 'ADMM attempted to create an atmosphere of security cooperation and dialogue within ASEAN rather than initiating substantial military cooperation. In this regard, ADMM would promote cooperation among the militaries of regional countries. In preparing the first ADMM, ASEAN cooperation introduced a new concept of "defence diplomacy" to forge positive and productive relationships among militaries in the region, leading to the creation and maintenance of a peaceful and stable security environment. Adopting defence diplomacy meant that the ADMM would be held as a mechanism to increase the level of interaction and enhance mutual trust and confidence, rather than based on threat perception. ADMM mechanism demonstrates the commitment of ASEAN to embark on an "official" multilateralism of security dialogue, in addition to the existing ARF and bilateral engagements' (Lianita, 2006).

The objectives, purposes and mechanism of the ADMM were laid out in the 2006 Concept Paper for the Establishment of the ASEAN Defence Ministers Meeting which was adopted at the inaugural ADMM meeting in Kuala Lumpur in 2006 and the 2007 Protocol to the Concept Paper for The Establishment of ASEAN Defence Ministers' Meeting. The 2006 Concept Paper laid out the general principles and objectives of the ADMM whereby it is stated that the 'The ADMM shall he the highest ministerial defence and security consultative and cooperative mechanism in ASEAN. It shall report directly to the ASEAN Heads of Government.' It further clarify that "ADMM shall complement other regional efforts which are promoting security dialogue and cooperation", with following specific objectives: "(a) to promote regional peace and stability through dialogue and cooperation in defence and security: (b) To give guidance to existing senior defence and military officials dialogue and cooperation in the field of defence and security within ASEAN and between ASEAN and dialogue partners;(c) to promote mutual trust and confidence through greater understanding of defence and security challenges as well as enhancement of transparency and openness; and (d)To contribute to the establishment of an ASEAN Security Community (A SC) as stipulated in the Bali Concord II and to promote the implementation of the Vientiane Action Programme (TAP) on ASC."

Overall the 2006 Concept Paper laid down an initial guideline and mechanism which was fairly general and clearly putting the ADMM as a dialogue forum rather than a regional security alliance. 
INTERNATIONAL JOURNAL OF ACADEMIC RESEARCH IN BUSINESS AND SOCIAL SCIENCES Vol. 9, No. 6, June, 2019, E-ISSN: 2222-6990 @ 2019 HRMARS

However, this is not to say that there was anything wrong with such an approach. Given the fact that the ADMM was largely threading uncharted ground and dealing with more countries than previous attempts at establishing a regional security collaboration organization, the 2006 ADMM concept paper had to be in such general terms to ensure initial support from ASEAN member states. Moreover, given ASEAN's principle of consensus, the 2006 ADMM concept paper was a prelude to a more refined outcome that would emerge from the discussions between the ASEAN countries prior to the 2nd ADMM held in Singapore in 2007. This was clearly seen by the contents of the Protocol to the concept paper for the establishment of the ADMM. The 2007 Protocol laid down a more detailed and codified mechanism and also bought under it already existing meetings between the ASEAN militaries under its purview and guidance thus resolving the previous state of affairs where the ASEAN militaries operated in their own closed sphere in regard to their military to military engagements.

\section{Analysis of Significant Achievement of ADMM}

The year 2018 marks a 12 years of the formalization of ADMM as a platform that allows for open and constructive dialogue on regional security issue of mutual interest at the ministerial level and promotes practical cooperation among the ASEAN Armed Forces. During the 12 years' term, ADMM has shown that its existence has contributed to the regions defence diplomacy activities. Its efforts to address the regions security challenges, at least, provides platform for discussion and dialogue, having the barrier of strict compliance to the non-interference to the internal conflict of members' nations.

The critical achievement of ADMM during the tenure is the formalization of ADMM as a tools to implement the envision concept of ASEAN security community. It enables the formalization of the military organisations' interactions mechanism through various level and collaborative discussion structures. Table 2 below shows the specific subject matter of collaborative constitution under ADMM.

TABLE 2

ADMM Collaborative Structure

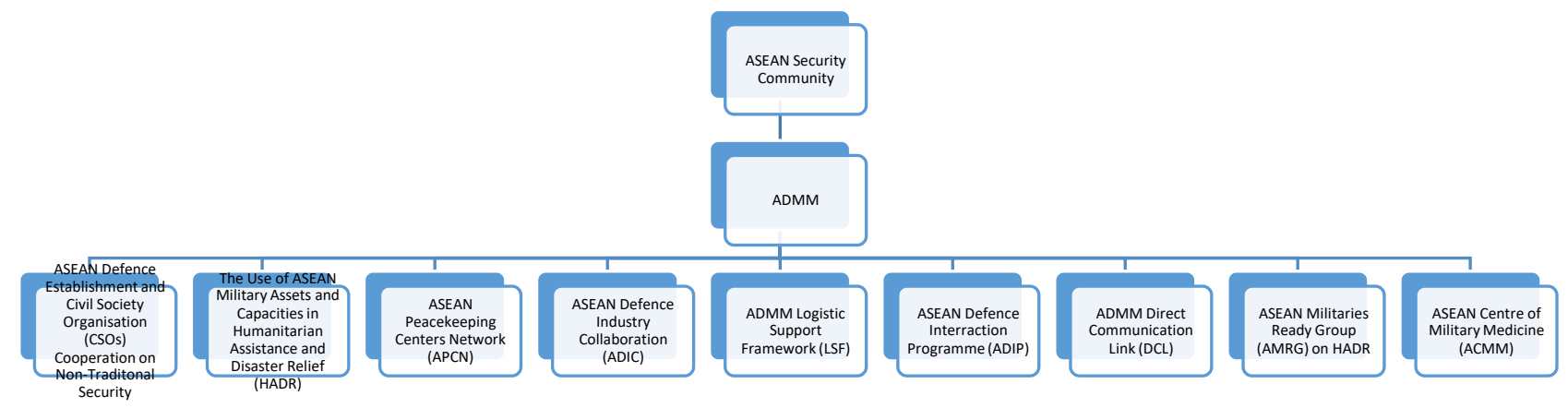

In addition, to the main framework, ADMM, through ADMM-PLUS has extended the collaboration to other eight non-ASEAN nations, namely, the US, China, Russia, Japan, India, South Korea, Australia and New Zealand. The extension is a part of implementing the policy ASEAN's openness, litheness and outward looking by engaging ASEAN's dialogue partners. The ADMM-Plus is 
tremendously succeeding in working toward achieving its objective by setting up various Expert Working Group (EWG) such as EWG on Humanitarian Mine Action, adopted at the $7^{\text {th }}$ ADMM, Bandar Seri Begawan, $7^{\text {th }}$ May 2013 and EWG on Cyber Security which was adopted at the $10^{\text {th }}$ ADMM, Vientiane, Laos, $25^{\text {th }}$ May 2016 to overseer activities and contribute to the security initiatives.

The most significant achievement of ADMM and ADMM Plus is the cooperation in the area of humanitarian assistance and disaster relief (HADR). For instances in June 2013 approximately 3200 personnel, seven ships, 15 helicopters and military medical assets from 18 nation involved in HADR and Military Medicine Exercise in Brunei Darussalam, the biggest and the first of its kind in the region. In the following years, at the $8^{\text {th }}$ ADMM held in Nay Pyi Taw, Myanmar (19-21 May) 2014, Brunei recommended the establishment of "a Direct Communication Link to keep the channel of communications open in the event of a crisis or emergency". The proposal was adopted by ADMM to provide quick response in handling crisis and emergency situations.

Much has been achieved by Maritime Security sector and could be regarded as the most active segment of ADMM. Maritime security meetings are done regularly. Until November 2016, maritime security division had accomplished $11^{\text {th }}$ ADMM-Plus Experts' Working Group on Maritime Security Meeting. Among the activities engaged by this sector are table-top exercise (3-7 September, 2012, Langkawi, Malaysia) (28-30 October, 2014, Brunei Darussalam), ADMM-Plus Maritime Security Field Training Exercise (29 September - 1 October, 2013, Jervis Bay and East Australian Exercise Area), Workshop on Counter-Piracy Operations (23-26 June, 2014, Auckland, New Zealand), Maritime Security Future Leaders' Programme (13-17 September, 2015, Auckland, New Zealand), ADMM-Plus Maritime Security and Counterterrorism Exercise (May, 2016, Singapore) and ADMM-Plus Maritime Security Exercise MAHI TANGAROA 16 (13-16 November, 2016 Auckland, New Zealand) (Retrieved from http://amscip.org/activities/ ).

In the field of Counter-terrorism and Peacekeeping Operations initiative, the ASEAN Convention on Counter-terrorism (ACCT) segment has prepared framework for regional cooperation to counter, prevent and supress terrorism and deepen counter terrorism cooperation. In addition, they have conducted the ADMM-Plus Counter Terrorism Exercise (CTX) (Indonesia - September 2013), ADMMPlus Table-Top Exercise (TTX) on Peacekeeping Operations (The Philippines - February 2014). In the area of Military Medicine, the ADMM has agreed to the establishment of ASEAN Military Medicine Coordination Centre (AMMCC) and had been working for the term of reference of its institution, while for the ASEAN Defence Industry Collaboration (ADIC) initiative seems to be not progressive and making little headway, and only recently finalised the framework for its implementation.

While much effort has been done by ASEAN and ADMM in particular, critiques on the implementation of the ADMM objectives evolves around the 'physical active' and 'real' achievement of ADMM in managing the defence and security issues in the region. This falls back to the ASEAN attitudes to discuss only the non-controversial issues and eventually left the controversial one. Huxley (2010) criticize that 'ADMM did a lot in terms of statement process and had a little to show in terms of concrete achievement'. He further argues that ADMM lack of ministerial mandate and therefore it would never be the venue to discuss defence issue at the highest level. The observation of Tim is relatively agreeable in the sense that ADMM and ASEAN, until now, could not resolve real security issues such as the Rohingyas', South China Sea dispute, piracy, terrorism and the kidnapping in the South Sulu Seas. The recent edition of ADMM which was held in Feb 2018, in Singapore, 
demonstrate the extend of action which the ADMM would engage, that is to 'condemn in strongest term' and in this case the act of terrorism while acknowledging the deadly and sophisticated method engaged by the terrorist. Despite that, ADMM remain relevant and important as an instrument of pacific conflict management and resolution in the ASEAN region. On the same note, Archaya (2009) argues that the current practice of ASEAN is no longer adequate to resolve regional conflict. According to Archaya (2009), ASEAN should make conflict resolution as part of its own agenda, rather than rhetoric condemnation, by establishing regional arbitration mechanism. However, this proposition is relatively impossible, in the view of current practice of ASEAN, and most of participating nations seems not ready to uplift the so called national interest to be judged by others.

\section{Conclusion}

The significant progress made by $A D M M$ in promoting security and defence cooperation is commendable. It provides avenue for militaries to sit together in a vague, loose and peaceful manner and execute defence diplomacy towards achieving intended output of the engagement. This arrangement does not prohibit nations to resort to alternative ways and courses in conflict resolution. The most recent example of collaborative effort outside ADMM was the Indonesia-MalaysiaPhilippines Trilateral Joint Working Group Meeting on the operationalization of the trilateral framework for cooperative arrangement specifically in combatting terrorism in Sulu Sea. This was done outside the ADMM framework for specific purposes. While, the way forward is more challenging, ADMM will remain as a dialogue platform as part of defence diplomacy initiatives rather than avenue for effective conflict resolution method, until ASEAN, radically changes its norm.

\section{Corresponding Author}

Mazura Md Saman, Lecturer, National Defence University of Malaysia, Sungai Besi Camp 57000 Kuala Lumpur, Malaysia, mazura.mdsaman@upnm.edu.my.

\section{References}

Acharya, A. (2009). Constructing a Security Community in Southeast Asia: ASEAN and the Problem of Regional Order (2nd edition). Oxford and London: Routledge.

Plesis, A. D. (2008). Defence Diplomacy: Conceptual and Practical Dimensions with Specific Reference to South Africa. Strategic Review for Southern Africa, 30(2).

ASEAN, Org. (2018) 'Concept Paper for the Establishment of an ASEAN Defence Ministers.pdf'. Retrieved from https://admm.asean.org/dmdocuments/1.

ASEAN, Org. (2018) 'Protocol to ADMM Concept Paper - 2. Protocol to the Concept Paper for the Establishment of the ADMM.pdf'. Retrieved from https://admm.asean.org/dmdocuments/2.

ASEAN. Org. (2018) 'History/ One Vision One Identity One Community'. ASEAN / ONE VISION ONE IDENTITY ONE COMMUNITY. Retrieved from http://asean.org/asean/about-asean/history/.

Berridge, G. R., James, A. and Barder, B. (Eds.).(2003). A Dictionary of Diplomacy (2 ${ }^{\text {nd }}$ ed). Basingstoke: Palgrave. p.66.

Bitzinger, R. A. (2011). 'U.S Defence Diplomacy Towards Southeast Asia'. In From 'Boots' to 'Brogues' The Rise of Defence Diplomacy in Southeast Asia, 104-15. RSIS Monograph 21. 
Bristow, D. (2005, April). 'The Five Power Defence Arrangements: Southeast Asia's Unknown Regional Security Organization'. Contemporary Southeast Asia Vol. 27(1). pp 1-20.

Cottey, A. \& Forster, A. (2004). Reshaping Defence Diplomacy: New Roles for Military Cooperation and Assistance, Adelphi Paper 365. Oxford, New York: Oxford University Press.

Edmonds, M. \& Mills, G. (1998). Beyond the Horizon: Defence, Diplomacy and South Africa's Naval Opportunities. S.I.: South African Institute of International Affairs and the Centre for Defence and International Security Studies.

Farrell, B. P. (2011). 'Southeast Asia Treaty Organization (SEATO)'. In Gordon Martel (Ed.). The Encyclopedia of War. Oxford, UK: Blackwell Publishing Ltd. Retrieved from http://doi.wiley.com/10.1002/9781444338232.wbeow584.

Henderson, C. (1998). IR: Conflict and Concept at the Turn of 21 ${ }^{\text {st }}$ Century. Singapore: McGraw Hill. Huxley, T. (2010). 'The ADMM Plus: What's Its for?' Nanyang Technological University, Singapore: S. Rajaratnam School of International Studies Nanyang Technological University.

Prawindarti, L. (2006, May 16). 'The First ASEAN Defence Ministers Meeting: An Early Test for the ASEAN Security Community?' IDSS Commentaries 34/2006.

Ooi, Keat Gin. (Ed.). (2004). Southeast Asia: A Historical Encyclopaedia, from Angkor Wat to East Timor. Vol. 1. Santa Barbara, Calif: ABC-CLIO. 